\title{
Comparison of Spatially Constrained Harvest Scheduling and a Classic Allowable Cut Indicator Approach for a Strip Shelterwood System
}

\author{
Marušák, R., Yoshimoto, A. \& Konoshima, M.
}

Keywords: mathematical programming, adjacency constraints, allowable cut indicator, optimization

Abstract: Forest management changed markedly in the Czech Republic and Slovakia after 1989. Following the denationalization of forestlands, forest managers became more concerned about sustainable timber production and the environmental impact of harvest operations. Current national forest laws in both countries prescribe a shelterwood silvicultural system, but clear-cutting according to harvest scheduling by allowable cut indicators is still the most widely used management system. As an alternative to allowable cut indicators, we investigate spatially constrained harvest scheduling under a shelterwood system. Our study design considers both spatial and non-spatial constraints. The first spatial constraint concerns adjacency - managers cannot simultaneously harvest trees from adjacent areas. The second is an environmental requirement to reserve a specific portion of the stand. Non-spatial constraints include factors such as the upper limit of harvest determined by an owner's harvest flow requirements. We developed and compared three alternatives, which employ different constraints to investigate their respective influence. We used integer programming to find the optimal solution for each alternative under spatially constrained harvest scheduling and compared these results with the allowable

Received September 29, 2010; Accepted February 9, 2011 


\begin{abstract}
cut indicators method. Our results showed that total net present value is smaller for the alternative with a reserve constraint and even flow harvest requirements. Moreover, in each simulation period, this alternative consistently minimized the difference in volume derived between the spatially constrained and allowable cut harvest scheduling systems. The difference in total cut and total net present value between the two harvest scheduling systems was $0.34 \%$ and $2.33 \%$, respectively.
\end{abstract}

\title{
1. Introduction
}

Forest management-especially harvest scheduling - was affected by socioeconomic and political changes that occurred after 1989 in the Czech Republic and Slovakia. Chief among these changes were the restitution of forest ownership to the original (private) owners and requirement of a silvicultural system that more closely mimics natural forest processes, as opposed to clear-cutting, which had become standard practice.

Historically, harvest scheduling in most Central European countries, especially in the Czech Republic and Slovakia, was conducted for large forest management units (FMU) with an area of thousands of hectares. Denationalization of forestlands has divided these FMUs into smaller units, typically with an area of tens or hundreds of hectares. The age structure of these newly formed FMUs is mostly unbalanced with a striking lack of mature stands.

For these FMUs, a shelterwood silvicultural system is recommended because it most closely mimics natural forest regeneration. The most common is a two-cut shelterwood silvicultural system, with a precommercial establishment or seeding cut, and final commercial cut. Shelterwood systems are divided into small- and large-scale systems based on the harvest strip size. A small-scale shelterwood system is limited to a strip area of 1 to 3 ha with a strip width less than double the mean stand height. A large-scale shelterwood system is limited to 
an area of 5 ha (up to 7.5 ha in some cases). Within the small-scale system, two cutting strategies can be used. In the first strategy, the shelterwood harvests take place on narrow strips adjacent to each other progressively and systematically with the seeding cut first, followed by the final cut; both harvests are made simultaneously on adjacent strips. Under the second strategy, shelterwood harvests on adjacent strips are made separately. If any cut occurs on one strip, no cut can be made on adjacent strips; seeding cuts cannot occur until all shelterwood harvests are completed on the adjacent strip. After the final cut is complete, a seeding cut is applied on one of the adjacent strips within a few years. In the Czech Republic and Slovakia, this strategy is called a small-scale partial shelterwood cut. In spruce stands, cut direction is specified to minimize windthrow damage, while beech stands are regenerated from north to south to take advantage of shade.

Although average FMU size has decreased and the clear-cutting rate is different than before, the classic approach of applying allowable cut indicators (ACI) to large FMUs managed by a clear-cutting silvicultural system remains in practice throughout much of the Czech Republic and Slovakia. Maximum allowable cut is also applied to the shelterwood system per forestry law. According to the law, total prescribed final cut for the planning period must be less than or equal to the ACI; however, several different ACIs can be derived. One approach is to use the maximum cutting percentage according to ACI.

There are several analyses of the regeneration, survival, and growth of young forest stands following the application of shelterwood cuttings (Barna, 1999, 2000, Drever and Lertzman, 2001, Granhus et al., 2003, Kneeshaw et al., 2002, Sendak et al., 2003). Studies about growth changes in mature forest stands during the regeneration period can be found in Marušák and Barna (2002) and Sedmák et al. (2006). In Solvakia, analyses of harvest scheduling are oriented toward clear- 
cutting and allowable cut indicators. Greguš $(1976,1983)$, Majoroš (2001) and Marušák (2001) have studied the advantages and disadvantages of using an allowable cut indicator, as well as its practical application in forest management. As these studies show, there is research on growth under a shelterwood system; however, there has been no analysis of harvest scheduling for this system. There are only a few analyses of ACI for forests managed under a shelterwood system. Šuška and Majoroš (1997) and Majoroš (1999) looked for alternatives to ACI in a small-scale forest. Their analysis examined adaptive regulation of final cut, taking into consideration current stand age and maturity. Marušák $(2001,2003)$ analyzed the age structure of newly created FMUs and evaluated empirical cutting percentages and areabased indicators for a shelterwood system as an alternative to ACI.

Mathematical programming is a useful tool to seek the optimal solution for harvest scheduling problems. It has been extensively used for the clear-cutting system. Early forest management models, such as Johnson and Scheurman (1977), Field et al. (1980), Leuschner (1990), and Hoganson and McDill (1993), were developed using linear programming. Since the late 1980s, spatial restrictions have been extensively introduced to account for new environmental regulations such as opening size limitations for clear-cutting, aesthetical considerations, and corridor development for wildlife. Examples include improved methods for including additional constraints on clear-cut opening size (Nelson and Brodie, 1990, Roise, 1990, Dahlin and Sallnas, 1993, Richards and Gun, 2003), the effects of different clear-cut restrictions on economic outputs (Barrett et al., 1998), and maximum clear-cut size (Kurttila, 2001, Boston and Bettinger, 2001, Murray and Weintraub, 2002). Spatial requirements have also been modeled for ecological and environmental aspects (Hof and Bevers, 2000, Kurttila, 2001), connectivity to road networks (Nelson and Finn, 1991), scenic and recreation values 
(Pukkala et al., 1995), optimizing wildlife and timber in a managed forest ecosystem (Hof and Joyce, 1993), land classification strategies (Borges and Hoganson, 2000), harvest clustering (Öhman and Lamas, 2003), and old growth patch size (Caro et al., 2003).

In light of smaller forest management units, national regulations, and an increasing number of additional environmental considerations, there is a need to find an optimal harvest scheduling regime for the shelterwood system. The spatial requirements for shelterwood cuts are one type of adjacency constraint; thus, the task can be described as a spatially constrained harvest scheduling problem.

The objective of this paper is to investigate spatially constrained harvest scheduling as an alternative to ACI under a shelterwood system. We consider the following constraints: (1) an ecological limit of the shelterwood system (represented by maximal area and strip width), which prohibits harvesting adjacent strips simultaneously; (2) a national limit on harvest level, represented by an allowable cut indicator; (3) an economic constraint representing landowners' requirements for even-flow harvest levels; and, (4) an environmental limit represented by the minimal area and minimum number of connected strips left uncut for wildlife habitat. We use integer programming to formulate the proposed problem. The objective is to maximize total cut volume over the planning horizon because harvest volume maximization is the primary objective of harvest scheduling in Slovakia.

\section{METHODS}

\subsection{The small-scale shelterwood system and management constraints}

Standard small-scale shelterwood forest management practice in the Czech Republic and Slovakia limits individual strip size within a stand 
to 3 ha and specifies that strip width must be less than twice the mean stand height. Several cutting methods can be used, and most are applied in a strip pattern. We investigate one cutting methoda small-scale partial shelterwood strategy — where harvest in adjacent strips is conducted independently. When a strip is regenerated after a final cut, seeding cuts can proceed on adjacent strips - simultaneous cuts in adjacent strips are not allowed. At least one strip adjacent to the harvested strip must be left uncut over the same period. In our study, we formulate adjacency constraints to represent this spatial harvest rule. Figure 1 shows an example of a three-stand case under the shelterwood system described above. Each stand (Fig.1a) can be divided into a certain number of strips. Let us assume that three strips are created in stands 1 and 2, and five strips in stand 3 (Fig.1b). If strip $a$ in stand 1 is harvested, strip $b$ cannot be harvested, but strip $c$ can be harvested. At the same time, strip $a$ in stand 3 cannot be cut together with strip $a$ in stand 1 .

a)

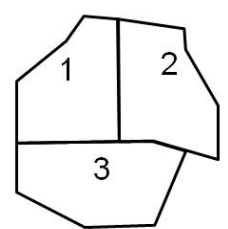

b)

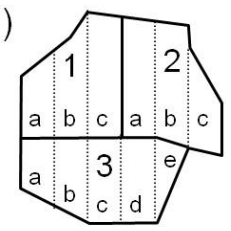

c)

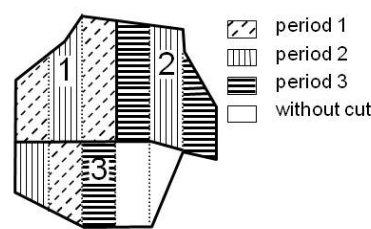

Figure 1. Three-stand shelterwood example

Table 1. Cutting percentage for ACI (rotation period 110, regeneration period 30 years)

\begin{tabular}{lccccc}
\hline Age class & 9 & 10 & 11 & 12 & 13 \\
\hline Cutting percentage $\left(\mathrm{cp}_{j}\right)$ & 4 & 30 & 50 & 88 & 100 \\
\hline
\end{tabular}

The volume of allowable cut indicator $\left(a c i_{j p}\right)$ at the $j$ th age class in
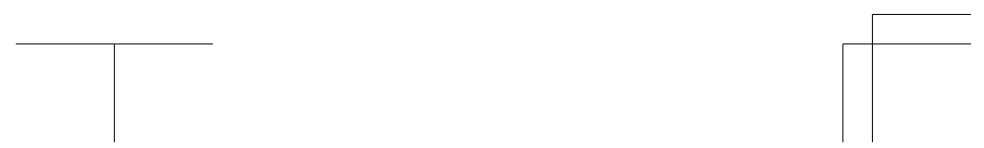
period $p$ is derived by the following:

$$
[1] \quad a c i_{j p}=\frac{v m_{j p} c p_{j}}{100}
$$

where $v m_{j p}$ is the volume of mature age class $j$ in period $p$, and $c p_{j}$ is the cutting percentage in age class $j$, as defined by applicable forest management laws (Tab.1). Age class is assigned at intervals of 10 years, starting at 1 ; an age class 1 indicates trees are 1 to 10 years old, age class 2 indicates trees are 11-20 years old, and so on. Mature age classes are defined according to the rotation and regeneration period. Age classes 9 and older are considered mature if the rotation period is 110 and the regeneration period is 30 years, as shown in Table 1 . Age classes younger than 9 are considered immature with 0 cutting percentage. The total allowable cut in period $p\left(A C I_{p}\right)$ is the sum of $\left\{a c i_{j p}\right\}$

$$
\text { [2] } \quad A C I_{p}=\sum_{j=9}^{J} a c i_{j p}
$$

This derived total $A C I_{p}$ is the upper limit for harvest within a forest management unit, and also depends on previous harvest. The value of $A C I_{p}$ is not fixed for all scenarios. Allowable cut indicators do not provide enough information to meet shelterwood system requirements because they do not consider spatial limits or constraints of the shelterwood system, such as limits on total cut during shelterwood harvests. Moreover, additional environmental or harvest flow requirements are not considered.

Environmental limits are generally specified by minimal area left uncut or the number of strips left uncut. (Similar requirements can be found in forest certification criteria, such as Forest Stewardship Coun- 
cil criterion 6.3). Shelterwood management systems typically set aside a number of strips as a shelter for wildlife. Let us assume two strips adjacent to each other are required for the three forest stands shown in Figure 1. When there is no harvest on strip $a$ in stand 1 , strip $\mathrm{b}$ in stand 1 or strip a in stand 3 must also be left uncut. Figure 1c depicts one possible solution for the three stands shown in Fig.1. No adjacent strips are cut in the same period and two adjacent strips - $\mathrm{d}$ and e in stand 3 - are left uncut at the end of the planning horizon.

Most landowners in the studied region seek to maximize total harvest under the shelterwood system. Long-term sustainable harvest is also a requirement of the forest management plan. In Slovakia, 3 periods or 30 years is the generally accepted horizon for defining sustainability. In addition to economic profit, private forest owners look for balanced harvests in each planning period (or yearly). This scenario keeps landowners employed harvesting and replanting throughout the year, and also secures a reliable supply of fuel wood for the owners and community.

\subsection{General formulation}

We formulate the shelterwood system as a 0-1 integer programming problem. The objective is to maximize total cut volume from all strips over $P$ planning periods, with one period equal to 10 years. Each strip is assigned to an age class (10-year range) based on its current age. To ensure forest regeneration, $P$ is set equal to the regeneration period:

[3] $\quad \max Z=\sum_{i=1}^{I} \sum_{j=1}^{J} \sum_{p=1}^{P} v_{i j p} \cdot x_{i j p}$

where $I$ is the total number of strips, $J$ is the total number of age classes, $P$ is the total number of planning periods, $v_{i j p}$ is the volume of the $i^{\text {th }}$ strip of the $j^{\text {th }}$ age class in period $p$, and $x_{i j p}$ is a control 
variable ( 0 or 1$)$ to specify the harvest of the $i^{\text {th }}$ strip of age class $j$ in period $p$ as defined by:

[4] $x_{i j p}=\left\{\begin{array}{cc}1 & \text { if the } i \text { th strip of the } j \text { th age class } \\ \text { in period } p \text { is harvested } \\ 0 \text { otherwise }\end{array}\right.$

Each strip in a forest stand can be cut only once over the planning horizon, or it can be left uncut, i.e.:

[5] $\quad \sum_{p=1}^{P} x_{i j p}+x_{i j 0}=1 \quad \forall i \in I, \forall j \in J$

where $x_{i j 0}$ is a control variable ( 0 or 1$)$ to specify a 'do nothing' treatment defined by:

[6] $\quad x_{i j 0}= \begin{cases}1 & \text { if the } i \text { th strip of the } j \text { th age class } \\ & \text { is left uncut } \\ 0 & \text { otherwise }\end{cases}$

\subsection{Spatial requirements}

Following Yoshimoto and Brodie (1994), strip adjacency constraints in our problem are formulated by:

$[7] \quad \mathbf{M} \cdot \mathbf{X}_{p} \leq \mathbf{C}$

where $\mathbf{X}_{p}$ is an $(\mathrm{n} \times 1)$ control vector of $\mathrm{n}$ control variables $x_{i j p}$ for the period $p$, ordered from the first strip of the first age class to the last strip of the last age class. In matrix notation $\mathbf{X}_{p}=\left(x_{11 p}, x_{21 p}, \ldots, x_{I J p}\right)^{T}$ is the control vector for the $p^{\text {th }}$ period, $T$ is transpose, and $n$ is the total number of strips. $\mathbf{M}=\mathbf{A}+\mathbf{B}$ is a modified adjacent matrix. $\mathbf{A}$ represents an $(n \times n)$ adjacency matrix. The elements of this adjacency 
matrix are equal to 1 if the $i^{\text {th }}$ and $j^{\text {th }}$ control variable in $\mathbf{X}_{p}$ cannot be implemented together for the same period, and 0 otherwise. $\mathbf{B}$ is a diagonal matrix in which the $i^{\text {th }}$ diagonal element represents the number $(r)$ of adjacent strips defined in the $i^{\text {th }}$ row of the $\mathbf{A}$ adjacency matrix. $\mathbf{C}$ is a $(\mathrm{n} \times 1)$ vector created by $r$, so that two adjacent strips cannot simultaneously be selected for harvest.

The environmental constraint requires leaving $m$ strips uncut over the planning horizon. Control variable $x_{i j 0}$ represents the 'do nothing' treatment. Our environmental constraint requires leaving at least two connected strips among $m$ strips uncut over the planning period. If one strip is not harvested, at least one of its adjacent strips must also be left uncut. The adjacency constraints are described by:

$$
\mathbf{A} \cdot \mathbf{X}_{0} \geq \mathbf{X}_{0}
$$

where $\mathbf{A}$ is an $(n \times n)$ adjacency matrix. $\mathbf{X}_{0}$ is a $(n \times 1)$ control vector $\mathrm{n}$ of control variables $x_{i j 0}$, ordered from the first strip of the first age class to the last strip of the last age class. In matrix notation $\mathbf{X}_{0}=\left(x_{110}, x_{210}, \ldots, x_{I J 0}\right)^{T}$.

The total number of uncut connected strips is determined by the following equation:

[9] $\quad \sum_{i=1}^{I} \sum_{j=1}^{J} x_{i j 0} \geq N$

where $N$ is the minimum number of connected strips.

The required area $(R A)$ of these strips is constrained within the minimum $\left(R A_{\min }\right)$ and maximum $\left(R A_{\max }\right)$ area by the following: 


$$
\begin{gathered}
\text { [10] } R A_{\min } \leq R A=\sum_{i=1}^{I} \sum_{j=1}^{J} a_{i j} \cdot x_{i j 0} \leq R A_{\max } \\
\forall i \in I, \forall j \in J_{i}
\end{gathered}
$$

where $a_{i j}$ is the area of the $i^{\text {th }}$ strip of the $j^{\text {th }}$ age class.

\subsection{Allowable cut}

The cut volume $\left(V_{p}\right)$ in each period over the planning horizon should be less than or equal to the allowable cut indicator $\left(A C I_{p}\right)$ :

$$
V_{p} \leq A C I_{p} \quad \text { for } p=1, \ldots, 3
$$

where:

[12] $\quad V_{p}=\sum_{i=1}^{I} \sum_{j=1}^{J} v_{i j p} \cdot x_{i j p} \quad$ for $p=1, \ldots, 3$

The $A C I_{p}$ in period $p$ is equal to the sum of the volume of the corresponding strips derived by the cutting percentage $\left(c p_{j}\right)$ of age class $j$.

$$
A C I_{p}=\sum_{i=1}^{I} \sum_{j=1}^{J} v_{i j p} \cdot c p_{j} \quad \text { for } p=1
$$

In periods where $p>1$ we must consider if strip $i$ of age class $j$ has already been cut. A cut strip is assumed to be replanted and its area thus belongs to the young age class with 0 cutting percentage. The volume of unharvested strips is only considered in ACI, by redefining the equation [13]: 
$[14]$

$$
\begin{aligned}
A C I_{p}= & \sum_{i=1}^{I} \sum_{j=1}^{J} v_{i j p} \cdot c p_{j} \\
& -\sum_{i=1}^{I} \sum_{j=1}^{J} v_{i j p} \cdot \sum_{k=1}^{P-1} x_{i j p-k} \quad \text { for } p=2, \ldots, P
\end{aligned}
$$

\subsection{Even flow constraints}

Sequential harvest flow constraints were used to meet the requirement for maximum percentage difference between two sequential periods. The percentage is represented by $\alpha$ or $\beta ; \alpha$ is the fractional reduction permitted in harvest level, while $\beta$ is the fractional increase permitted.

$$
(1-\alpha) V_{p-1} \leq V_{p} \leq(1+\beta) V_{p-1}
$$

\section{Case study}

A forest managed by the School Forest Enterprise of the Technical University in Zvolen (Central Slovakia) was used for our case study. The Enterprise manages various forests for their owners. We selected one spatially complete FMU owned by a single individual. The FMU's area - 950 ha - is very close to the average FMU size in Slovakia. The rotation period in this forest is 110 years, with a regeneration period of 30 years. Growth data for this FMU was obtained in 2003 from the regular forest inventory. Dominant tree species include beech (69\%) and spruce (13\%); broadleaves account for $86 \%$ of cover and coniferous species $14 \%$. The mean site index of beech is 30 and spruce is $34^{* 1}$.

The number of forest stands available for harvest in the next three

*1 Range of site indices is 10 to 38 for beech and 14 to 42 for spruce. The higher the site index, the higher the production. 
periods was 68 with a total area of 592.60 ha. Each forest stand was divided into strips following small-scale shelterwood management guidelines (i.e. limited strip area and width). There were a total of 616 strips with an average area of 0.96 ha. An adjacency matrix was derived for these strips, revealing a total of 321 adjacency constraints for each period (after accounting for redundant elements). Three environmentally important regions were identified within the forest with a total area of 163.73 ha. At least 4\% (6.55 ha) of these regions must be left uncut, and at least two physically connected strips must remain in each of the three regions. There were 174 adjacency constraints identified for environmental requirements.

A small-scale shelterwood system was applied to this forest using a planning horizon of 30 years ( 3 periods of 10 years - a typical management practice in Slovakia) for optimization. Thirty years also corresponds to the regeneration period. Three alternatives (A-C) for the shelterwood system were proposed to investigate the influence of constraints (Tab.2). The upper limit of allowable cut and adjacency constraint were included in all alternatives. A maximum $10 \%$ fluctuation between two sequential periods was used as harvest flow constraints in alternatives $\mathrm{A}$ and $\mathrm{B}$. This requirement was only applied to periods 2 and 3 because there was no data available about real harvest before the planning horizon period. The environmental limit (6.55 ha left uncut) was applied to alternative A.

In addition to alternatives $\mathrm{A}, \mathrm{B}$, and $\mathrm{C}$, we also calculated a maximum shelterwood cut, following small-scale rules, which only considered adjacency constraints without any periodic harvest volume requirements. This cut represents maximum possible harvest, in light of area and width constraints placed on the strips, without any concern for allowable cut, harvest flow, or environmental limits. We calculated maximum cut to investigate the influence of additional constraints on 
harvest flow and environmental reserves.

Table 2. Overview of constraints considered in alternatives A-C

\begin{tabular}{ccccc}
\hline Alternative & Allowable cut in & Environmental & Harvest flow & Adjacency \\
& period $\mathrm{p}(\mathrm{ACI})$ & limit $(6.55 \mathrm{ha})$ & $(10 \%)$ & constraints \\
\hline A & Yes & Yes & Yes & Yes \\
B & Yes & No & Yes & Yes \\
C & Yes & No & No & Yes \\
\hline
\end{tabular}

Forest stand volume over the planning periods was derived from the product of the volume at the beginning of each planning horizon $\left(V_{i j 1}\right)$ and incremental coefficients for age class $\left(c_{j}\right)$ :

$$
V_{i j p}=V_{i j-1, p-1} \cdot c_{j} \quad \forall i \in I, \forall j \in J, \quad p=2,, P
$$

where $V_{i j p}$ is the volume of the $i^{\text {th }}$ part of age class $j$ in period $p$. For period $1(p=1), V_{i j 1}$ is equal to the initial volume from the forest management plan. Subsequent volume levels are derived by equation [16]. The values used for the $c_{j}$ coefficients are frequently used to predict volume and harvest development in Slovakia (Marušák, 1999).

Net present value (NPV) was also calculated to compare alternative solutions and the costs of environmental and harvest limit requirements. Average wood prices (EUR 50.30/ $\mathrm{m}^{3}$ ) and felling costs (EUR $32.83 / \mathrm{m}^{3}$ ) were taken from the Green Report (2008). An interest rate of $4.25 \%$ based on a 2008 average in Slovakia - was used for the analysis, and ILOG CPLEX 10.1 software was used to solve the proposed problems.

\section{Results}

We compared maximum shelterwood cut and ACI in each period in terms of volume harvested and NPV. Alternatives A-C were also 
Table 3. Cut volume $\left(\mathrm{m}^{3}\right)$ and net present value $\left(\times 10^{3} \mathrm{EUR}\right)$ of ACI, maximum shelterwood cut, and alternatives A-C (net change in ACI reported in brackets)

\begin{tabular}{|c|c|c|c|c|c|c|}
\hline \multirow{2}{*}{ Alternative } & & \multicolumn{3}{|c|}{ Period } & \multicolumn{2}{|c|}{ Total } \\
\hline & & 1 & 2 & 3 & Volume & NPV \\
\hline \multirow{2}{*}{ ACI } & Cut & 93,352 & 90,201 & 79,565 & \multirow{2}{*}{263,118} & \multirow{2}{*}{2.031} \\
\hline & NPV & 1.012 & 0.645 & 0.375 & & \\
\hline \multirow{2}{*}{$\begin{array}{l}\text { Maximum } \\
\text { shelterwood }\end{array}$} & Cut & $87,765(-5.98)$ & $85,472(-5.24)$ & $90,546(13.80)$ & 263,783 & 1.989 \\
\hline & NPV & 0.951 & 0.611 & 0.427 & $(0.25)$ & $(-2.10)$ \\
\hline \multirow{3}{*}{ A } & Cut & $87,414(-6.36)$ & $87,410(-3.09)$ & $87,410(9.86)$ & 262,234 & 1.984 \\
\hline & NPV & 0.947 & 0.625 & 0.412 & $(-0.34)$ & $(-2.33)$ \\
\hline & $\mathrm{AC}^{\mathrm{a}}$ & 93,352 & 101,541 & 87,414 & - & - \\
\hline \multirow{3}{*}{$\mathrm{B}$} & Cut & $79,500(-14.84)$ & $87,450(-3.05)$ & $96,192(20.90)$ & 263,142 & 1.940 \\
\hline & NPV & 0.862 & 0.625 & 0.453 & $(0.01)$ & $(-4.50)$ \\
\hline & $\mathrm{AC}^{\mathrm{a}}$ & 93,352 & 108,996 & 96,192 & - & - \\
\hline \multirow[t]{3}{*}{$\mathrm{C}$} & Cut & $30,378(-67.46)$ & $111,362(23.46)$ & $125,898(58.23)$ & 267,638 & 1.719 \\
\hline & NPV & 0.329 & 0.796 & 0.593 & $(1.72)$ & $(-15.40)$ \\
\hline & $\mathrm{AC}^{\mathrm{a}}$ & 93,352 & 160,336 & 125,898 & - & - \\
\hline
\end{tabular}

Note: $\quad \mathrm{AC}^{\mathrm{a}}-$ represents upper harvest limit of alternative in each period

compared to ACI and maximum shelterwood cut to evaluate differences in cut volume and net present value. All results are shown in Table 3 and Figures 2-3.

\subsection{Comparison of ACI and maximum shelterwood cut}

Given the initial age structure, the total harvestable volume for this forest using ACI was 93,352 $\mathrm{m}^{3}$ for the first period. Because ACI was estimated using the clear-cutting silvicultural system, it did not include any constraints from the shelterwood system. Its value in the first period was $5,587 \mathrm{~m}^{3}(5.98 \%)$ greater than the value derived from maximum shelterwood cut. In period 2, ACI yielded 4,729 $\mathrm{m}^{3}(5.24 \%)$ 
more than maximum shelterwood cut (Tab.3). In period 3, however, maximum shelterwood cut yielded 10,981 $\mathrm{m}^{3}(13.80 \%)$ more than ACI. The same relative differences in NPV were obtained.

The total volume derived under ACI from the complete three period planning horizon was $263,118 \mathrm{~m}^{3}, 665 \mathrm{~m}^{3}(0.25 \%)$ less than total volume from the maximum shelterwood scenario $\left(263,783 \mathrm{~m}^{3}\right)$. On the other hand, total NPV was EUR $42(2.10 \%)$ higher than the NPV for the maximum shelterwood cut. Figure 2a, which is a comparison of cut derived under ACI and maximum shelterwood cut, shows that the volume under maximum shelterwood cut and ACI differed with an opposite trend. While volume decreased in the second and third periods under ACI, it increased during period three under the maximum shelterwood scenario. The same comparison for NPV is shown in Figure $2 \mathrm{~b}$.

\subsection{Alternative A}

Under alternative A, all shelterwood system guidelines were followed and the cut was kept below the upper limit established by national regulations. An environmental constraint was also applied, requiring a minimum of two adjacent strips with an area of at least 6.55 ha be left intact. In our simulation, a total of 8.14 ha were left uncut.

The harvest flow requirement was set to a maximum $10 \%$ cut fluctuation between successive periods. Figure 3a provides a comparison with $\mathrm{ACI}$ and the other alternatives. In comparison to ACI, the cut volume was $5,938 \mathrm{~m}^{3}(6.36 \%)$ and $2,791 \mathrm{~m}^{3}(3.09 \%)$ less in both the first and second periods, respectively. On the other hand, it was 7,845 $\mathrm{m}^{3}(9.86 \%)$ more than ACI in the third period. The cut volume was balanced over the planning horizon in this alternative. Total harvest was $262,234 \mathrm{~m}^{3}$, which was $0.34 \%\left(884 \mathrm{~m}^{3}\right)$ less than the volume derived under ACI (Tab.3). The resultant NPV of alternative A over the 

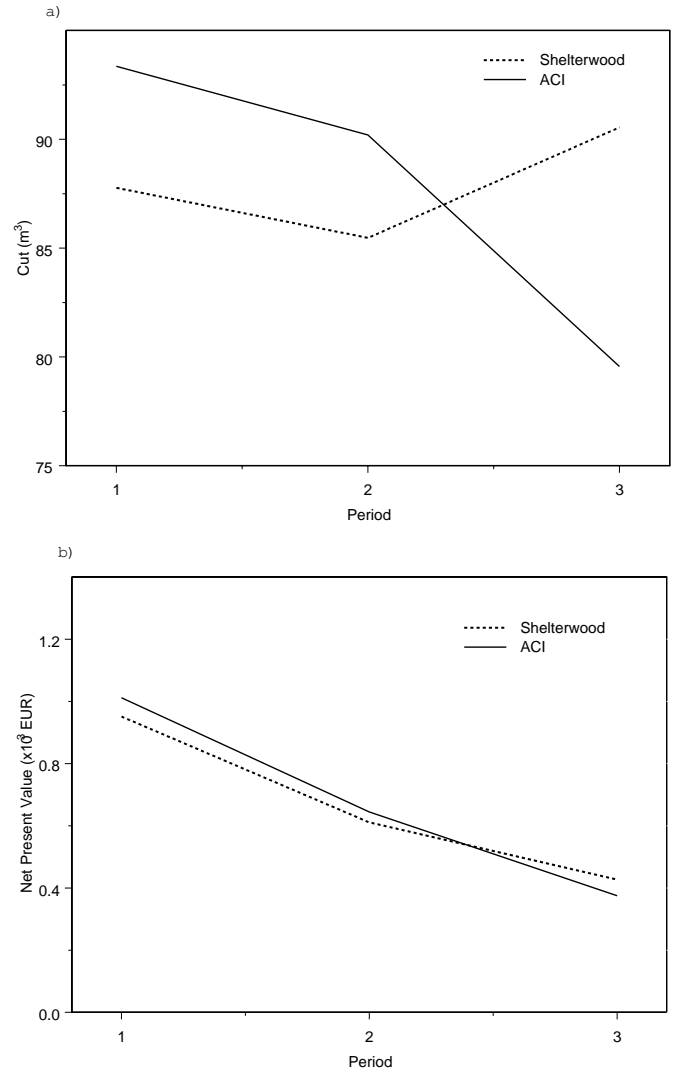

Figure 2. Cut (a) and net present value (b) of the allowable cut indicator (ACI) and shelterwood system

planning horizon was about 2.33\% less than ACI (Fig.3b).

There was no major difference when we compared this alternative with maximum shelterwood cut. The total cut volume derived by alternative A was $1,949 \mathrm{~m}^{3}$ (0.74\%) less and total NPV EUR 5 (0.25\%) less than maximum shelterwood cut. 


\subsection{Alternative B}

Alternative $\mathrm{B}$ differed from $\mathrm{A}$ in that no environmental constraint was applied. As the objective of our optimization was to maximize total harvest, the minimum cut of this alternative was achieved in the first period and the maximum cut in the third (Fig.3a). Differences between the cut volume derived with this alternative and ACI were greater than that obtained under alternative $\mathrm{A}$, but the trends were similar - volume under ACI was greater in the first and second periods and less in the third period.

Total cut under alternative B was nearly the same as ACI, with a difference of only $24 \mathrm{~m}^{3}$ (0.01\%) (Tab.3). However, total NPV was less than ACI because cut volume was greater in the first period under ACI. The difference was EUR 91 (4.50\%).

When comparing this alternative with maximum shelterwood cut, total cut volume was $641 \mathrm{~m}^{3}$ less and total NPV was EUR 49 less. In comparison to alternative A, total cut was $908 \mathrm{~m}^{3}$ greater, but total NPV was EUR 44 less. A solution with no environmental constraints was considered, which yielded greater cut volume $(0.35 \%)$, but $2.22 \%$ lower NPV compared to the solution with environmental constraints.

\subsection{Alternative $\mathrm{C}$}

Alternative C resulted in the greatest total harvest of $267,638 \mathrm{~m}^{3}$, as neither environmental nor even flow harvest requirements were considered. Total harvest was $4,520 \mathrm{~m}^{3}(1.72 \%)$ more than ACI (Tab.3) and harvests under this alterative were unbalanced (Fig.3a). Differences were greater than the set boundaries of $10 \%$ in alternatives A and $\mathrm{B}$. Despite this, the volume in each period was less than the upper limit set by allowable cut because nationally established volume limits depend on the age and volume structure in each period, which are a result of harvest in the previous period. If less is cut in the first period, more 

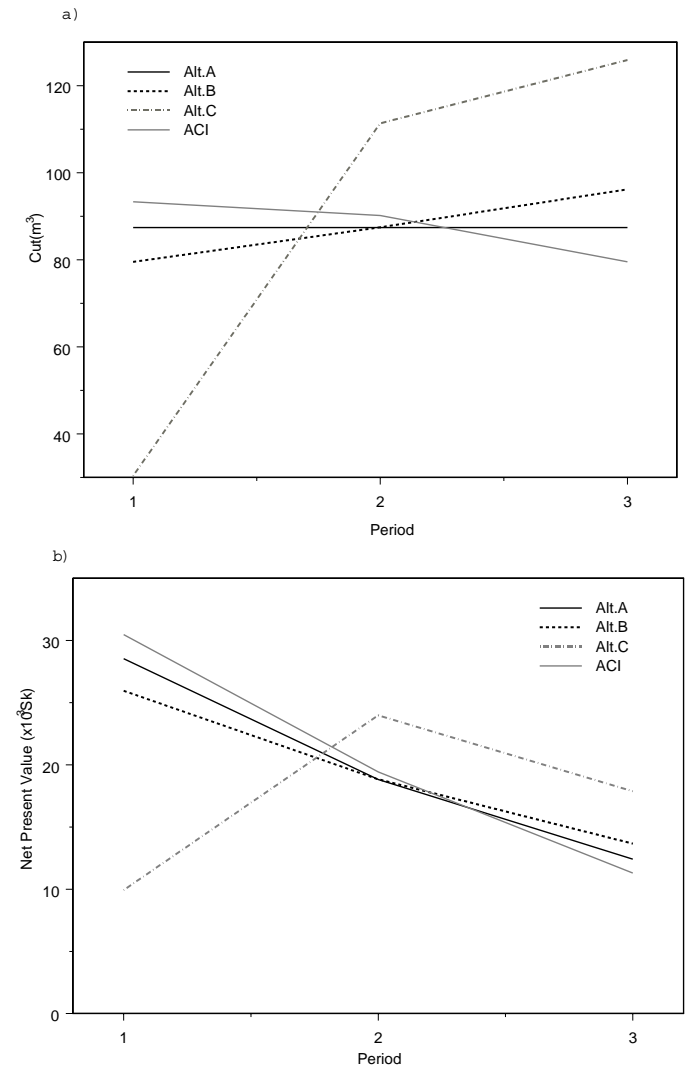

Figure 3. Cut (a) and net present value (b) of alternatives A-C within the planning horizon

can be cut in the second, and vice versa.

Differences in cut derived by this alternative and by ACI were the greatest in all periods, varying from $-67.46 \%$ to $58.23 \%$. Total cut derived under this alternative was the greatest of all solutions, but total NPV was the least. This was the result of an extremely low cut $\left(30,378 \mathrm{~m}^{3}\right)$ in the first period and an extremely high cut $\left(125,898 \mathrm{~m}^{3}\right)$ in the third period. Figure $3 \mathrm{~b}$ shows NPV for this alternative in all 
three periods. In comparison to alternative A, total cut was $5,404 \mathrm{~m}^{3}$ $(2.06 \%)$ greater, but total NPV was EUR 265 (13.38\%) less. When comparing this alternative with maximum shelterwood cut, total cut was $3,855 \mathrm{~m}^{3}$ (1.46\%) greater, but total NPV was EUR 270 (13.59\%) less.

\section{Conclusions}

This paper dealt with a spatially constrained harvest scheduling problem for a partial cut shelterwood system. A case study was conducted using a 950 ha forest management unit in Zvolen, Slovakia. A smallscale, two-cut shelterwood system was used to manage this forest. The planning horizon was set to 3 periods (30 years), which corresponds with the regeneration period. In addition to the area and strip width limits imposed by the shelterwood system, which were considered as stand level requirements, upper harvest limits (taken from nationally established limits) and harvest flow over time were taken into account as forest level requirements. Environmental requirements to leave certain connected areas uncut, as well as adjacency requirements, were formulated as spatial constraints.

Forest managers have traditionally used allowable cut indicators (ACI) - based on clear-cutting principles - for the shelterwood system in Slovakia. Three spatially constrained harvest scheduling alternatives (A-C) were considered to investigate the influence of harvest flow and environmental constraints; these alternatives were also compared to ACI. The least difference in total cut, when compared to maximum shelterwood cut, was obtained under alternative B, where periodic allowable cut, harvest flow, and adjacency constraints were included. On the other hand, less difference in total NPV, when compared to maximum shelterwood cut, was obtained under alternative A, where constraints for environmental area, even flow harvest, adjacency, and 
periodic allowable cut were considered. Alternative A also provided balanced cuts over the planning horizon. Moreover, the difference between the volume derived by this alternative and volume under ACI was minimized in each period, as was the difference in total NPV. This alternative provided lower total cut volume than alternatives $\mathrm{B}$ and C, but total NPV was greater.

Our results confirm that it is inappropriate to use cutting percentage from ACI as a management guideline. The cut specified by ACI violates small-scale shelterwood management guidelines in the first and second periods. ACI also does not ensure appropriate forest regeneration in the third period. Additionally, ACI only speaks to volume and does not provide spatial information about where harvest should take place. Using ACI as a guideline, managers will fail to secure the area and meet strip width limits of the shelterwood system. Our results show that total volume derived from a shelterwood cut over the planning horizon is greater than that derived from ACI. Furthermore, the shelterwood management guidelines provided information about which strip should be cut in each period, and produced a balanced cut over the planning horizon. The proposed spatially constrained harvest scheduling scenario can be used as an alternative to ACI in the management of Slovakian forests. This scenario considers spatial information and makes it possible to include other limits such as environmental or harvest flow requirements.

\section{Acknowledgements}

This research was kindly supported by the Czech Republic Ministry of Agriculture, project number QH91077: "Integrated non-monetary and economic valuation of biodiversity as a base potential of forest functions," and by the Japan Society for the Promotion of Science (JSPS). We would like to express our gratitude for financial support 
provided by Ecosystem Adaptability Global COE at Tohoku University to attend and present this research at the FORMATH international symposium in Tachikawa, Tokyo, Japan, March 2010.

\section{References}

Barna, M. (1999) Process of twig growth of beech (Fagus sylvatica L.) of dominant and codominant trees after regeneration cutting, Ekológia (Bratislava) 3: 233-245.

Barna, M. (2000) Impact of shelterwood cutting on twig growth in predominant beech trees (Fagus sylvatica L.), Ekológia (Bratislava) 4: $341-353$.

Barrett, T.M., Gilless, J.K. and Davis, L.S. (1998) Economic and fragmentation effects of clearcut restrictions, Forest Sci. 44: 569-577.

Borges, J.G. and Hoganson, H.M. (2000) Structuring a landscape by forestland classification and harvest scheduling spatial constraints, Forest Ecol. Manag. 130: 269-275.

Boston, K. and Bettinger, P. (2001) The economic impact of greenup constraints in the southeastern United States, Forest Ecol. Manag. 145: 191-202.

Caro, F., Constantino, M., Martins, I. and Weintraub, A. (2003) A 2-opt tabu search procedures for the multiperiod forest harvesting problem with adjacency, green-up, old growth, and even flow constraints, Forest Sci. 49 (5): 738-751.

Dahlin, B. and Sallnas, O. (1993) Harvest scheduling under adjacency constraints: a case study from the Swedish sub-alpine region, Scand. J. Forest Res. 8: 281-290.

Drever, C.R. and Lertzman, K.P. (2001) Light-growth responses of coastal Douglas-fir and western redcedar saplings under different regimes of soil moisture and nutrients, Can. J. Forest Res. 31: $2124-2133$. 
Field, R.C., Dress, P.E. and Fortson, J.C. (1980) Complementary linear and goal programming procedures for timber harvest scheduling, Forest Sci. 26: 121-133.

Granhus, A., Brække, F.H., Hanssen, K.H. and Haveraaen, O. (2003) Effects of partial cutting and scarification on planted Picea abies in partially cut stands in southeast Norway, Scand. J. Forest Res. 18: $237-246$.

Greguš, C. (1976) Hospodárska úprava maloplošného rúbaňového lesa. Príroda, Bratislava, 304 pp.

Greguš, C. (1983) Výpočet etátu pomocou empirických t'ažbových percent, Lesnícky časopis-Forestry Journal (29), 3: 251-267.

Hof, J. and Joyce, L.A. (1993) A mixed integer linear programming approach for spatially optimizing wildlife and timber in managed forest ecosystem, Forest Sci. 39 (4): 816-834.

Hof, J. and Bevers, M. (2000) Optimal timber harvest scheduling with spatially defined sediment objectives, Can. J. Forest Res. 30: 14941500.

Hoganson, H.M. and McDill, M.E. (1993) More on forest regulation: An LP perspective, Forest Sci. 39: 321-347.

Johnson, K.N. and Scheurman, H.L. (1977) Techniques for prescribing optimal timber harvest and investment under different objectivesdiscussion and synthesis, For. Sci. Monogr. 18: 31.

Kneeshaw, D.D., Williams, H., Nikinmaa, E. and Messier, C. (2002) Patterns of above- and below-ground response of understory conifer release 6 years after partial cutting, Can. J. Forest Res. 32: 255265.

Kurttila, M. (2001) The spatial structure of forests in the optimization calculations of forest planning: a landscape ecological perspective, Forest Ecol. Manag. 142: 129-142.

Leuschner, W.A. (1990) Forest regulation, harvest scheduling and plan- 
ning techniques, John Wiley \& Sons, Inc. 281.

Majoroš, Š. (1999) Overenie možnosti adaptívnej regulácie obnovných t'ažieb súboru podrastovo obhospodarovaných porastov, Acta Facultatis Forestalis Zvolen, XLI, 211-224.

Majoroš, Š. (2001) Alternativne možnosti t'ažbovej úpravy adaptívnymi ukazovatel'mi, Acta Facultatis Forestalis Zvolen, XLIII 209-218.

Marušák, R. (1999) Problematika výchovných t'ažieb pri kalkulácii očakávaných zásob, Acta Facultatis forestalis Zvolen, XLI, 225-238.

Marušák, R. (2001) Possibilities of using of allowable cut indicators in shelterwood system, In: Gadow Kv, Nagel J, Saborovski J (Eds.): Continuous Cover Forestry - Assessment, Analysis, Scenarios, International IUFRO Conference, Göttingen, Germany, p. 195-202.

Marušák, R. and Barna, M. (2002) Response of diameter increment of beech stand on shelterwood cut phases, Ekológia (Bratislava), 21, Supplement 2/2002: 91-98.

Marušák, R. (2003) Harvest scheduling and close to nature forestry, In: Novotný J (Ed.): Close to nature forestry, Forest Research Institute Zvolen, 28-37.

Murray, A.T. and Weintraub, A. (2002) Scale and unit specification influences in harvest scheduling with maximum area restrictions, Forest Sci. 48 (4): 779-789

Nelson, J. and Brodie, J.D. (1990) Comparison of a random search algorithm and mixed integer programming for solving area-based forest plans, Can. J. Forest Res. 20: 934-942.

Nelson, J. and Finn, S.T. (1991) The influence of cut-block size and adjacency rules on harvest levels and road networks, Can. J. Forest Res. 21: 595-600.

Öhman, K. and Lamas, T. (2003) Clustering of harvest activities in multiobjective long-term forest planning, Forest Ecol. Manag. 176: 161-171. 
Pukkala, T., Nuutinen, T. and Kangas, J. (1995) Integrating scenic and recreational amenities into numerical forest planning, Landscape Urban Plan. 32: 185-195.

Richards, E.W. and Gunn, E.A. (2003) Tabu search design for difficult forest management optimization problems, Can. J. Forest Res. 33: 1126-1133.

Roise, J.P. (1990) Multicriteria nonlinear programming for optimal spatial allocation of stands, Forest Sci. 36 (3): 487-501.

Sedmák, R., Barna, M. and Marušák, R. (2006) Radial growth responses to shelterwood cutting in beech (Fagus sylvatica) stands. In: Furst, Ch., et al. (Eds.) Future-oriented Concepts, Tools and Methods for Forest Management and Forest Research Crossing European Borders, Proceedings of the Virtual Conference ForwardFORESTs, 111-119.

Sendak, P.E., Brissette, J.C. and Frank, R.M. (2003) Silviculture affects composition, growth, and yield in mixed northern conifers: 40-year results from the Penobscot Experimental Forest, Can. J. Forest Res. 33: 2116-2128.

Šuška, M. and Majoroš, Š. (1997) Teoretické princípy a a využitie adaptívnej regulácie a kontroly rubných t'ažieb, Vedecké štúdie 10/1997/A, TU Zvolen, pp. 57.

Yoshimoto, A. and Brodie, J.D. (1994) Comparative analysis of algorithm to generate adjacency constraints, Can. J. Forest Res. 24: 1277-1288. 